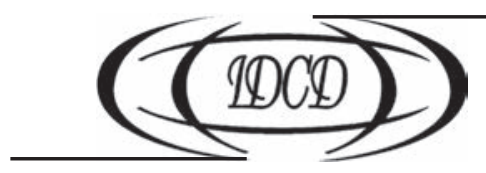

Doi: https://doi.org/10.15407/dse2017.02.029

УДК[314.5+314.3+314.186](476+477)

JEL CLASSIFICATION: J11, J12, J13

\title{
И.А. КУРИЛО
}

д-р экон. наук, проф.

Институт демографии и социальных исследований им. М.В. Птухи НАН Украины 01032, г. Киев, бул. Т. Шевченко, 60

E-mail: iryna.kurilo2017@gmail.com

\section{С.Ю. АКСЕНОВА}

канд. экон. наук, вед. науч. сотруд.

Институт демографии и социальных

исследований им. М.В. Птухи НАН Украины

01032, г. Киев, бул. Т. Шевченко, 60

E-mail: svitlana_aksyonova@yahoo.com

\section{Л.И. СЛЮСАР}

канд. экон. наук, вед. науч. сотруд.

Институт демографии и социальных

исследований им. М.В. Птухи НАН Украины

01032, г. Киев, бул. Т. Шевченко, 60

E-mail:1.slyusar@bigmir.net

\section{БРАЧНОСТЬ, РОЖДАЕМОСТЬ И ВОСПРОИЗВОДСТВО МАТЕРИНСКОГО ПОКОЛЕНИЯ В БЕЛАРУСИ И УКРАИНЕ: ОПЫТ СРАВНИТЕЛЬНОГО АНАЛИЗА}

Статья посвящена характеристике общих черт и отличительных особенностей современной ситуации в сфере рождаемости и формирования семей в Украине и Беларуси на основе сравнительного анализа брачно-семейных процессов, рождаемости и воспроизводства материнского поколения в этих странах за последнее пятнадиатилетие. Схожесть современной модели брачно-семейного поведения населения Украины и Беларуси обусловлена территориальной близостью, общими чертами этнического состава населения, развитием семьи и брака на протяжении ХХ века по общему «советскому сценарию». При сохранении многих традиционных черт семейного образа жизни (в т. ч. высокого уровня брачности), в обеих странах ныне меняется возрастная модель брачности: сокращается доля ранних браков, повышается средний возраст вступления в брак. Наиболее острой проблемой как украинской, так и белорусской семьи является нестабильность брачных отношений. Однако высокий уровень разводимости в значительной степени связан и с высокой зарегистрированной брачностью: в обеих странах официально зарегистрированный брак (таrriage) является основной формой брачных отношений, хотя получает все большее распространение и незарегистрированное брачное сожительство (cohabitation). Исследуемый период в иелом ознаменовался повышением уровней рождаемости и воспроизводства материнского 
поколения в обеих странах при сохранении преимущества за Беларусью, общим для обеих стран «постарением материнства». Вместе с тем, выявлены различия в динамике доли внебрачных рождений, определенная асинхронность темпов изменения рождаемости в Украине и Беларуси, существенность межстрановых различий в уровнях рождаемости и темпах их динамики в разных типах поселений. Как показал анализ, именно отличия в рождаемости являются более весомым (по сравнению со смертностью женщин в репродуктивном возрасте) фактором, определяющим межсттрановую разнииув современном уровне воспроизводства материнского поколения.

Ключевые слова: сравнительный межстрановой анализ, брачность, разводимость, рождаемость, воспроизводство материнского поколения.

\section{I.O. Курило}

д-р екон. наук, проф.

Інститут демографії та соціальних досліджень

ім. М.В. Птухи НАН України

01032, м. Київ, бул. Т. Шевченка, 60

E-mail: iryna.kurilo2017@gmail.com

\section{С.Ю. Аксьонова}

канд. екон. наук, пров. наук. співроб.

Інститут демографії та соціальних досліджень

ім. М.В. Птухи НАН України

01032, м. Київ, бул. Т. Шевченка, 60

E-mail: Svitlana_Aksyonova@yahoo.com

\section{Л.І. Слюсар}

канд. екон. наук, пров. наук. співроб.

Інститут демографії та соціальних досліджень

ім. М.В. Птухи НАН України

01032, м. Київ, бул. Т.Шевченка, 60

E-mail: L.Slyusar@bigmir.net

\section{ШЛЮБНІСТЬ, НАРОДЖУВАНІСТЬ І ВІДТВОРЕННЯ МАТЕРИНСЬКОГО ПОКОЛІННЯ В БІЛОРУСІ ТА УКРАЇНІ: ДОСВІД ПОРІВНЯЛЬНОГО АНАЛІЗУ}

Стаття присвячена характеристиці спільних і відмінних рис сучасної ситуації у сфері народжуваності та формування сімей в Україні та Білорусі на основі порівняльного аналізу шлюбно-сімейних процесів, народжуваності та відтворення материнського покоління в цих краӥнах за останнє п'ятнадиятиріччя. Схожість сучасної моделі шлюбно-сімейної поведінки населення України і Білорусі обумовлена їхньою територіальною близькістю, спільними рисами етнічного складу населення, розвитком сім'ї та шлюбу протягом ХХ століття за загальним «радянським сценарієм». За збереження багатьох традиційних рис сімейного способу життя (ут. ч. високого рівня шлюбності), в обох країнах нині змінюється вікова модель шлюбності: скорочується частка ранніх шлюбів, підвищується середній вік вступу до шлюбу. Найгострішою проблемою як української, так і білоруської сім'ї є нестабільність шлюбних відносин. Однак високий рівень розлучуваності значною мірою пов'язаний і з високою зареєстрованою шлюбністю: в обох країнах офіційно зареєстрований шлюб (marriage) є основною формою шлюбних відносин, хоча набуває все більшого поширення і незареєстроване шлюбне співжиття (cohabitation). Досліджсваний період у цілому ознаменувався загальним для обох країн «постарінням материнства», підвищенням рівнів народжуваності та відтворення материнського покоління за збереження переваги за Білоруссю. Водночас, виявлено відмінності в динаміці частки позашлюбних народжень, певну асинхронність темпів змін народжуваності в Україні і Білорусі, істотність міжкраїнних розбіжностей у рівнях народжуваності та темпах їх динаміки в різних типах поселень. Як показав аналіз, саме відмінності у народжуваності є більш вагомим (порівняно зі смертністю жінок у репродуктивному віці) фактором, що визначає різницю між країнами щодо сучасного рівня відтворення материнського покоління.

Ключові слова: порівняльний міжкраїнний аналіз, шлюбність, розлучуваність, народжуваність, відтворення материнського покоління. 


\section{I.O. Kurylo}

Dr. Sc. (Economics), Prof.

Ptoukha Institute for Demography and Social Studies

of the National Academy of Sciences of Ukraine

01032, Ukraine, Kyiv, blvd. Taras Shevchenko, 60

E-mail: iryna.kurilo2017@gmail.com

\section{L.I. Slyusar}

Ph.D. (Economics), Leading Scientific worker

Ptoukha Institute for Demography and Social Studies

of the National Academy of Sciences of Ukraine

01032, Ukraine, Kyiv, blvd. Taras Shevchenko, 60

E-mail: L.Slyusar@bigmir.net

\section{S.Yu. Aksyonova}

$\mathrm{PhD}$ (Economics), Leading Scientific Worker

Ptoukha Institute for Demography and Social Studies

of the National Academy of Sciences of Ukraine

01032, Ukraine, Kyiv, blvd. Taras Shevchenko, 60

E-mail: Svitlana_Aksyonova@yahoo.com

\section{MARRIAGE, FERTILITY AND REPRODUCTION OF THE MOTHER'S GENERATION IN BELARUS AND UKRAINE: THE EXPERIENCE OF COMPARATIVE ANALYSIS}

The article is devoted to the description of the common and distinctive features of fertility and family formation in Ukraine and Belarus on the basis of comparative analysis of marriage and family processes, fertility and reproduction of the mother's generation in these countries over the last fifteen years. The similarity of the modern model of marriage and family behavior of the population in Ukraine and Belarus is due to the territorial proximity, the comparable ethnic composition of the population, and the general «Soviet scenario» of family and marriage development throughout the twentieth century. While many of the traditional features of the family lifestyle (including a high level of nuptiality) have persisted at the beginning of this century, the age model of marriage is now changing in both countries: the share of early marriages is declining, and the average age of marriage is increasing. The most acute problem in Ukrainian and Belarusian families is the instability of marriage relations. However, the high divorce rate is associated with high registered marriage rate: in both countries officially registered marriage is the main form of marriage, although cohabitation (unregistered marriage) is becoming more widespread. The study period was marked by ageing motherhood and the increase of fertility and the mother's generation reproduction rates in both countries, but, in comparison with Ukraine, Belarus has higher indicators. At the same time, we identified a difference in the share of births out of wedlock, a certain asynchrony of dynamics of the fertility rates in Ukraine and Belarus, and cross-country variance in fertility rates and dynamic in different types of settlements. According to the study, the differences in fertility are more significant factor (in comparison with the mortality of women in the reproductive age) which determines the cross-country variance in the reproduction of the mother's generation.

Keywords: comparative cross-country analysis, marriage, divorce, fertility, reproduction of the mother's generation.

Постановка проблемы и анализ имеющихся публикаций. Объяснение и прогнозирование современных социально-демографических тенденций невозможно без изучения многообразия их проявлений, включая как выделение их общих черт, так и оценку степени различий в этом многообразии. Сравнительный межстрановой (межрегиональный) анализ незаменим в изучении процессов демографической конвергенции / дивергенции, которое на сегодня представляет одно из центральных направлений в социально-демографической исследовательской проблематике.

Применение сравнительного анализа необходимо и для определения общих и специфических факторов демографической динамики в разных странах: еще 
Э. Дюркгейм (E. Dyurkgeym) подчеркивал, что сравнительная методология подчинена поиску и выявлению причинно-следственных связей в сравниваемых объектах $[1$, с. 514].

Отличительной особенностью современных отечественных демографических исследований, в которых так или иначе присутствует сравнительный контекст, является сопоставление отечественных значений показателей с теми их уровнями, которые достигнуты в более развитых европейских странах или же в целом в ЕС и для Украины могут считаться эталонными ${ }^{1}[2,3]$. Учитывая ориентацию на европейский вектор развития с преобладанием его «догоняющей» стратегии, выбор такого исследовательского ракурса вполне оправдан, однако он может оказаться недостаточным для осмысления всего многообразия факторов и пространственновременных проявлений общеевропейских демографических тенденций, а также специфики демографической модернизации в нашей стране, а, следовательно, и для принятия обоснованных решений в сфере социально-демографической политики. Здесь необходим учет того исторически сформировавшегося, довольно устойчивого социокультурного фона развития и особенностей институционального устройства, которые, в числе прочих факторов, детерминируют возможности и темпы социально-демографических трансформаций. Особенно он важен применительно к сфере брачно-семейных процессов и рождаемости, тенденции развития которых, как нам представляется, определяются влиянием институциональных и социокультурных факторов в большей степени, нежели остальных процессов.

Исходя из этого, сопоставление современных тенденций соответствующих демографических процессов в Украине и в тех странах, с которыми ее связывает близкое соседство, общее историческое бытие и прошлое социокультурное развитие, может также быть весьма полезным в плане обогащения исследовательского и прогностического потенциала сравнительного демографического анализа. При этом в центр такого исследования целесообразно поставить прежде всего проблемы различий в конкретных обстоятельствах места и времени.

Среди имеющихся исследований такого плана следует выделить работу Л. Слюсар и О. Гагауз (L. Slyusar \& O. Gagauz), посвященную сравнительному анализу брачности [4], исследование C. Аксеновой и О. Гагауз (S. Aksyonova \& O. Gagauz) с подробным анализом рождаемости в Украине и Молдове [5], комплексное исследование демографического «профиля» Украины и России, проведенное С. Пирожковым и Г. Сафаровой (S. Pirozhkov \& G. Safarova) [6], диссертацию B. Ревун (V. Revun), изучавшую демографическое развитие Беларуси, России и Украины в условиях депопуляции [7], а также исследование группы учёных, в которую входили Е. Андреев, Ж. Валлен, П. Григорьев, Д. Жданов и др. (Е. Andreev, J. Vallin, P. Grigoriev, D. Jdanov), посвященное различиям в тенденциях смертности в трех вышеупомянутых странах [8].

В рамках двустороннего проекта «Основные вызовы демографической безопасности: сходства и различия в Беларуси и Молдове» под руководством Г. Палади, Л. Шахотько, О. Гагауз (G. Paladi, L. Shahotko \& O. Gagauz) было проведено сравнительное исследование динамики основных демографических процессов (рождаемость, смертность, миграция) в Молдове и Беларуси, в котором определены общие тенденции для обеих стран, а также выявлены особенности их демографического развития [9].

\footnotetext{
${ }^{1}$ Не случайно наиболее распространены сравнения именно показателей смертности и продолжительности жизни, применительно к которым эталонность и желательность уровней, достигнутых в более развитых странах, представляется однозначной и не вызывает сомнений.
} 
Безусловного внимания заслуживает также недавняя работа группы исследователей из разных стран, посвященная анализу тенденций рождаемости и опыта семейной политики в Центральной и Восточной Европе после 1990 года [10], однако она преимущественно направлена на формирование целостной картины изменений в данной сфере и обобшение опыта семейной политики в указанном регионе.

Украина и Беларусь рассматривались в рамках комплексных либо тематических социально-демографических исследований, проведенных в свое время по странам СНГ [11, 12]. Вместе с тем, попыток исследований, сфокусированных на сравнительном анализе ситуации в сфере брачности-разводимости, а также рождаемости и воспроизводства материнского поколения в этих двух странах за последнее десятилетие предпринято не было. При этом интерес представляет, на наш взгляд, также рассмотрение современной ситуации в Беларуси и Украине на фоне других стран, относящихся к разным регионам европейского континента.

Цель данной работы состоит в том, чтобы охарактеризовать общие черты и отличительные особенности современной ситуации в сфере рождаемости и формирования семей в Украине и Беларуси на основе сравнительного анализа матримониальных процессов, рождаемости и воспроизводства материнского поколения в этих странах за последнее пятнадцатилетие.

Изложение основного материала. Украина и Беларусь - территориально ближайшие соседи (протяжённость общей границы составляет около 1084,2 км), и имеют много общего в «демографической истории». Однако различия в этническом составе населения, а следовательно в традициях и ментальности, в размере страны и объеме ее экономического потенциала, в численности населения и уровне урбанизации (городское население в Беларуси ныне превышает 3/4, а в Украине составляет 2/3 общей численности), а также в уровне и направленности социально-экономического развития детерминируют определенную национальную специфику демографических тенденций, в том числе отличительные особенности присущей им современной модели брачности и рождаемости.

В первые десятилетия XXI века население Украины и Беларуси в значительной степени сохранило традиции семейного образа жизни, присущие странам, находящимся восточнее «линии Хайнала» (Hajnal) - высокую брачность, семейную солидарность поколений. Вместе с тем трансформация брака и семьи, которая происходит в той или иной форме во всех странах западной цивилизации, наблюдается и в каждой из рассматриваемых стран, характеризуясь своими особенностями.

Украина и Беларусь относятся к странам Европы с высокой интенсивностью брачно-семейных процессов, высокими показателями как брачности, так и разводимости. Так, в 2014 г. в Беларуси было зарегистрировано наибольшее в Европе количество браков в расчете на 1000 населения, а «впереди» Украины по этому показателю были лишь Россия, Литва и Молдова (рис. 1).

Линия тренда коэффициентов брачности свидетельствует об умеренном росте уровня брачности в Беларуси на протяжении последних 15 лет и об отсутствии существенных его изменений в Украине (рис. 2).

Привлекает внимание, что в обеих странах наблюдаются значительные годовые колебания, обусловленные сохранившейся традицией считать високосные годы неблагоприятными для заключения брака: число зарегистрированных браков неуклонно уменьшается в високосные годы (2000, 2004, 2008, 2012 гг.), а в пред- и послевисокосные увеличивается. 


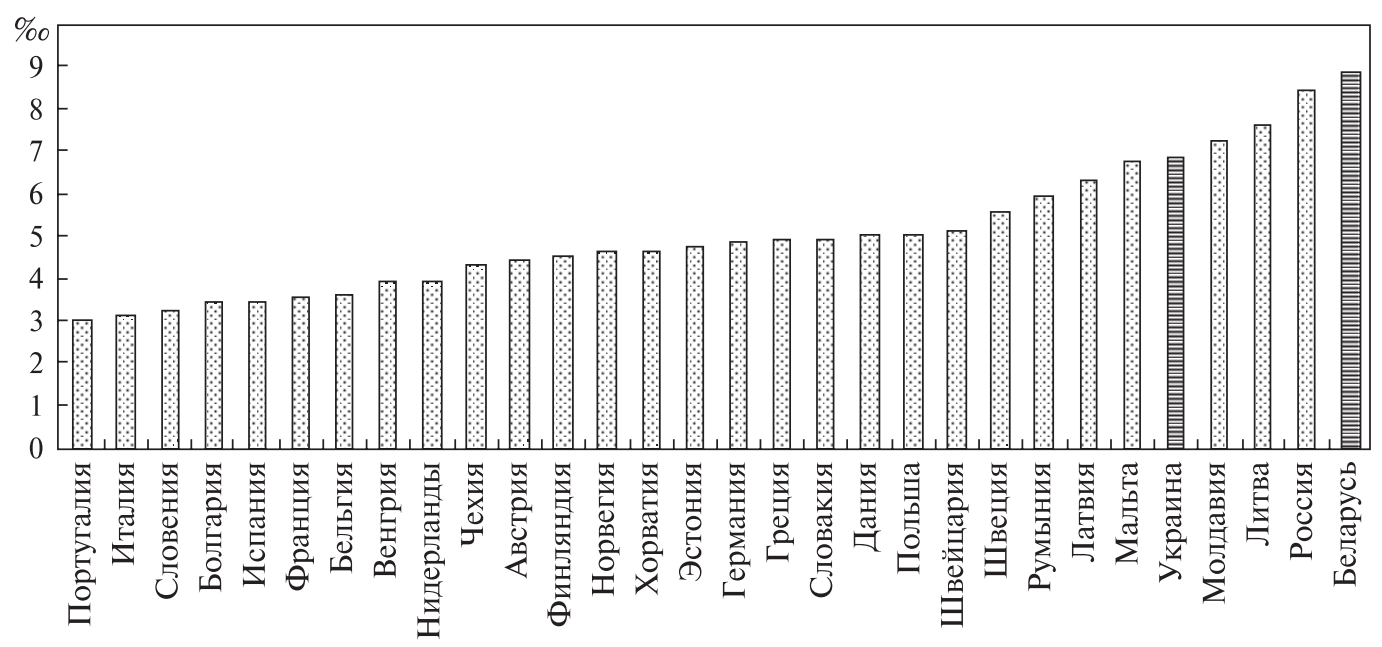

Puc. 1. Общий коэффициент брачности в Украине, Беларуси и некоторых других странах Европы в 2014 г., \%о

Источник: данные Евростата (http://www.epp.eurostat.ec.europa.eu/tgm/table).

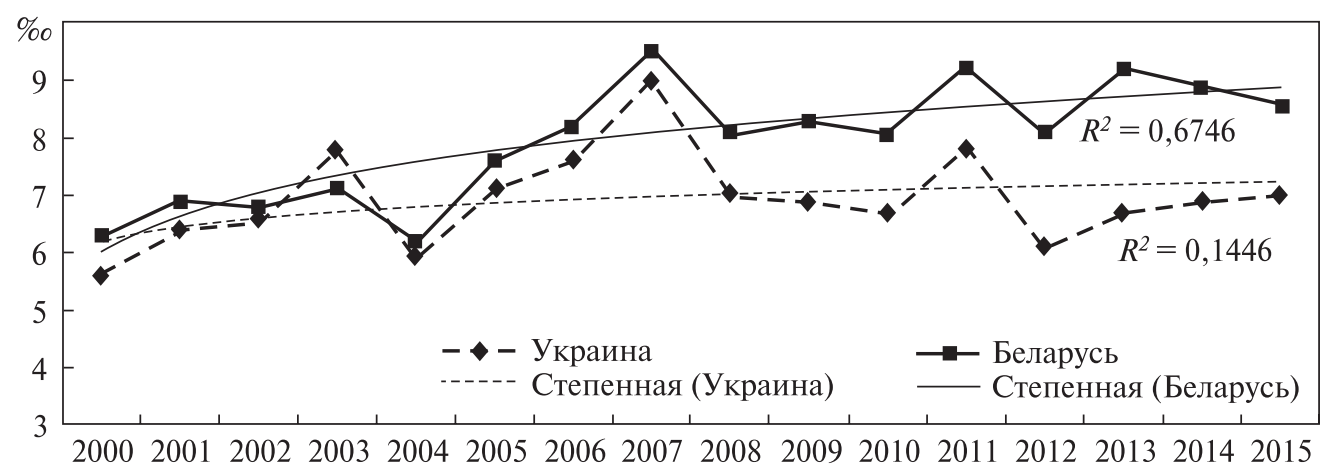

Pис. 2. Общий коэффициент брачности в Украине и Беларуси в 2000-2015 гг., \%о

Источник: Демографический ежегодник Республики Беларусь. Статистический сборник / Национальный статистический комитет Республики Беларусь. - Минск, 2016. - (http://www.belstat.gov.by); данные Государственной службы статистики Украины (http://www.ukrstat.gov.ua/).

Сравнительный анализ уровня брачности городского и сельского населения Украины и Беларуси еще раз подтверждает схожесть динамики этого показателя при более позитивной направленности тренда в городах и сельской местности Беларуси. Кроме того, различия в уровне брачности городского и сельского населения в Беларуси больше, чем в Украине, хотя в обеих странах в городах заключается большее количество браков на 1000 жителей, чем в сельской местности, что обусловлено более старой возрастной структурой сельского населения (рис. 3).

Для оценки уровня брачности также используется суммарный коэффициент брачности $(T N R)$, т. е. количество браков на одного мужчину и одну женщину брачного 


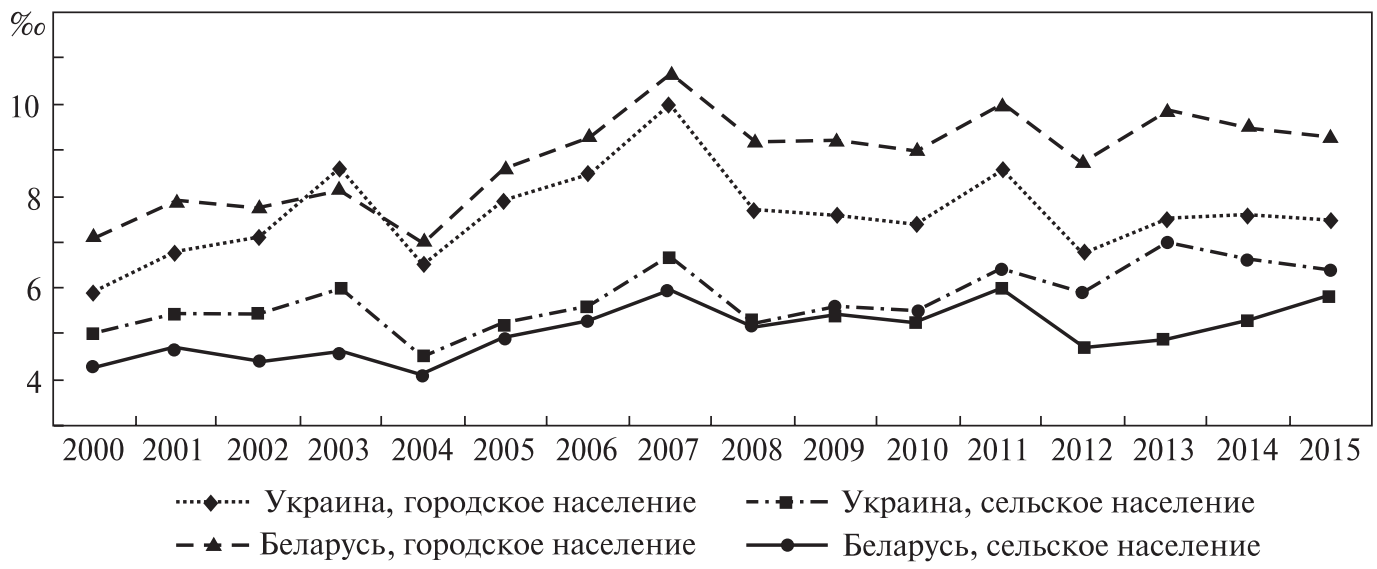

Puc. 3. Общий коэффициент брачности в городских поселениях и сельской местности Украины и Беларуси в 2000-2015 гг., \%о

Источник: Демографический ежегодник Республики Беларусь. Статистический сборник. - Минск, 2016; данные Государственной службы статистики Украины.

возраста из условного поколения. По нашим расчетам, в последние пять лет в Беларуси этот показатель колебался на уровне 1,2 (у мужчин 1,07-1,23; женщин 1,09-1,27), в Украине - около 1,0 (у мужчин 0,82-1,04; женщин 0,84-1,06). Самые низкие показатели фиксируются в високосные годы. Уровень брачности в обеих странах по европейским меркам остается высоким, вместе с тем и по суммарному, и по общему коэффициенту зарегистрированная брачность в Беларуси выше, чем в Украине. Это подтверждает и сравнительный анализ повозрастных коэффициентов брачности: во всех возрастных группах и женщин и мужчин, за исключением женщин 18-19 лет, в Беларуси эти показатели выше, чем в Украине.

Официально зарегистрированный брак (marriage) - основная форма брачных отношений в Украине и Беларуси, вместе с тем, как и в других странах Европы, формы брачного партнерства становятся более разнообразными, незарегистрированное брачное сожительство (cohabitation) стало обычным явлением, и количество таких союзов постепенно увеличивается. По данным переписей раунда 2000 года, в Беларуси 5,4 \% всех браков были официально не зарегистрированы (перепись 1999 г.), в Украине - 7 \% (перепись 2001 г.). Перепись раунда 2010 года не была проведена в Украине, что ограничивает возможность сравнительного анализа, и все таки определенные сопоставления возможны: в Беларуси согласно переписи 2009 г. 8 \% брачных союзов (8,2 \% у мужчин и 8,1 \% у женщин) не были зарегистрированы, в Украине, по данным нескольких выборочных обследований 2008-2010 гг., таких союзов $10-12 \%$.

Можно предположить, что брачные союзы без регистрации более распространены в Украине, чем в Беларуси, и косвенно это подтверждает более высокий уровень внебрачной рождаемости в Украине. За последние десять лет различия между странами по этому показателю значительно увеличились: в Беларуси после 2005 г. удельный вес внебрачных рождений быстро снижается, а в Украине фактически стабилизировался на уровне 21-22 \% (рис. 4). 


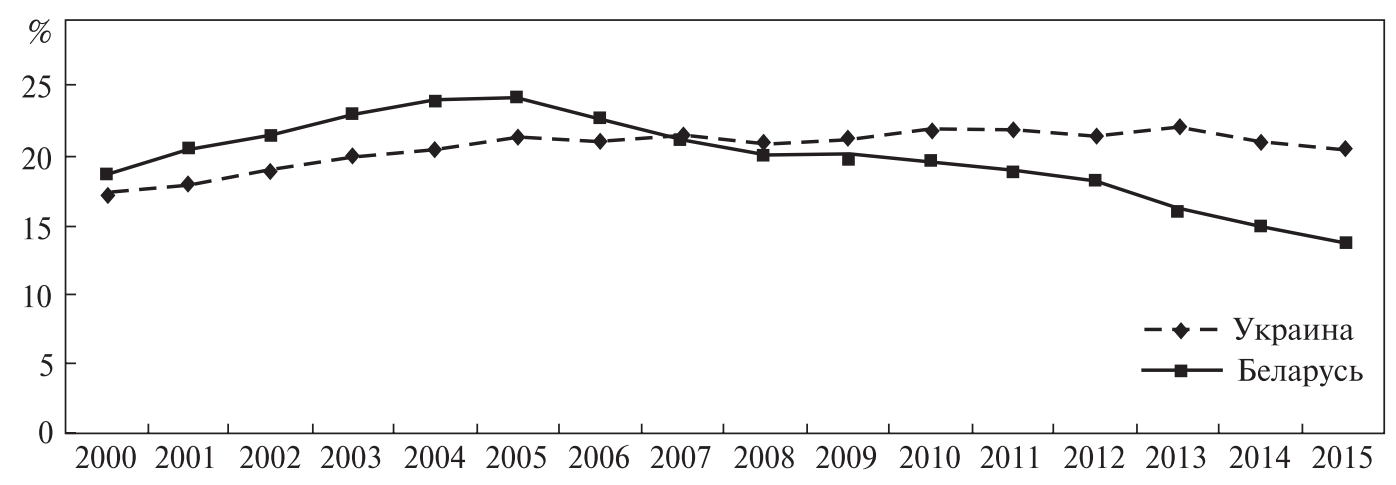

Рис. 4. Доля внебрачных рождений в Украине и Беларуси в 2000-2015 гг., \%

Источник: Демографический ежегодник Республики Беларусь. Статистический сборник. - Минск: 2016; данные Государственной службы статистики Украины.

В обеих исследуемых странах меняется возрастная модель брачности: заключение брака все чаще откладывается до завершения периода получения профессионального образования и приобретения специальности. За 2000-2015 гг. в Беларуси средний возраст вступления в первый брак для женщин вырос с 22,8 до 25,5 лет, мужчин - с 25,0 до 27,5 лет, в Украине с 22,5 лет до 25,1 и с 25,3 до 27,6 года соответственно, то есть «постарение» брачности идет практически синхронно (табл. 1).

Таблица 1. Средний возраст вступления в первый брак и доля повторных браков в Украине и Беларуси в 2000 и 2005-2015 гт.

\begin{tabular}{|c|c|c|c|c|c|c|c|c|}
\hline \multirow{2}{*}{ Год } & \multicolumn{2}{|c|}{ Средний возраст первого брака, лет } & \multicolumn{3}{c|}{ Доля повторных браков, \% } \\
\cline { 2 - 9 } & \multicolumn{2}{|c|}{ мужчины } & \multicolumn{2}{|c|}{ женщины } & \multicolumn{2}{|c|}{ мужчины } & \multicolumn{2}{c|}{ женщины } \\
\cline { 2 - 9 } & Украина & Беларусь & Украина & Беларусь & Украина & Беларусь & Украина & Беларусь \\
\hline 2000 & 25,3 & 25,0 & 22,5 & 22,8 & 26,7 & 25,2 & 25,6 & 24,4 \\
\hline 2005 & 25,9 & 25,7 & 23,2 & 23,5 & 25,4 & 23,7 & 24,3 & 23,0 \\
\hline 2006 & 25,9 & 25,8 & 23,3 & 23,6 & 24,2 & 22,8 & 23,2 & 22,6 \\
\hline 2007 & 26,0 & 25,9 & 23,4 & 23,8 & 23,6 & 23,5 & 22,7 & 23,0 \\
\hline 2008 & 26,3 & 26,0 & 23,7 & 23,9 & 24,8 & 24,0 & 24,2 & 23,5 \\
\hline 2009 & 26,5 & 26,4 & 24,0 & 24,2 & 24,7 & 24,6 & 23,9 & 24,6 \\
\hline 2010 & 26,7 & 26,5 & 24,1 & 24,4 & 24,2 & 24,6 & 23,4 & 24,6 \\
\hline 2011 & 26,8 & 26,6 & 24,3 & 24,5 & 23,8 & 24,3 & 23,1 & 24,3 \\
\hline 2012 & 27,0 & 26,7 & 24,5 & 24,6 & 24,7 & 25,7 & 24,4 & 25,9 \\
\hline 2013 & 27,3 & 27,1 & 24,8 & 25,0 & 25,3 & 26,6 & 25,1 & 26,5 \\
\hline 2014 & 27,4 & 27,4 & 24,9 & 25,3 & 25,8 & 27,3 & 25,9 & 28,1 \\
\hline 2015 & 27,6 & 27,5 & 25,1 & 25,5 & 24,9 & 27,4 & 25,5 & 28,8 \\
\hline
\end{tabular}

Источник: Демографический ежегодник Республики Беларусь. Статистический сборник. - Минск: 2016; данные Государственной службы статистики Украины. 
При том, что возрастные характеристики брачности в современной Украине и Беларуси отличаются мало, брак в обеих странах остается «моложе», чем в большинстве стран Европы. Так, средний возраст вступления в первый брак женщин в 2014 г. в Украине составлял 24,9 года, в Беларуси - 25,3, тогда как в Польше - 26,7, Чехии - 28,7, Германии - 30,7, Швеции - 33,3 года.

Традиционно и в Беларуси, и в Украине женщины вступают в брак в более раннем возрасте, чем мужчины. Гендерные различия в возрастных коэффициентах брачности в этих странах одинаковы: у женщин выше, чем у мужчин, уровень брачности в возрасте до 25 лет, у мужчин - выше в возрастных группах старше 25. Однако следует отметить, что если среди мужчин в обеих странах наивысшие показатели брачности фиксируются у лиц в возрасте 20-29 лет, то у женщин наблюдаются определенные отличия: у беларусских женщин самые высокие возрастные коэффициенты в группе 20-24-летних, затем - у 18-19 и 25-29-летних, у украинских же - в группе 20-24-лет, затем - среди 18-19-летних. Женщины Украины начинают супружескую жизнь несколько раньше и более «активны на брачном рынке» в возрасте до 20 лет.

Ранние браки (невеста в возрасте до 18 лет) в обеих странах на сегодня регистрируются редко, их доля в общем количестве браков в 2015 г. в обеих странах составляла менее $1 \%$ (рис. 5). Вместе с тем в предыдущие десятилетия для Украины ранняя брачность (особенно в сельской местности) была значительно более характерна, чем для Беларуси: в 1995 г. в Украине такие браки составляли 10,9 \% всех браков, в 2000 г. - 7,2 \%, а в Беларуси в эти годы 5,3\% и 2,8 \% соответственно. Это является продолжением традиций ранней брачности, которые были более характерны для Украины, что отразилось в нормах семейного кодекса и способствовало консервации этой традиции. В Беларуси единый брачный возраст в 18 лет для обоих полов был установлен еще в 1926 г., а в Украине до 1968 г. брачный возраст женщин составлял 16 лет, мужчин - 18, с 1968 г. - соответственно 17 и 18 лет, и эти нормы перешли в Семейный кодекс, принятый в 2004 году. Лишь в марте 2012 г. в Семейный кодекс Украины были внесены изменения, в соответствии с которыми брачный возраст женщин был повышен с 17 до 18 лет, т. е. уравнен с мужским.

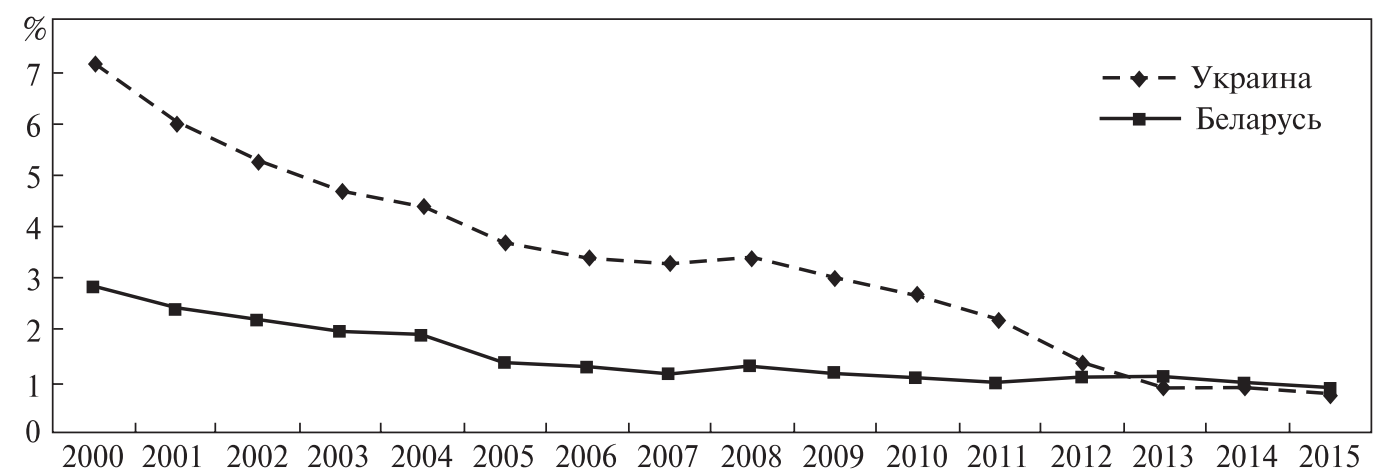

Рис. 5. Удельный вес ранних браков (невеста в возрасте до 18 лет) среди всех браков, регистрируемых в Украине и Беларуси в 2000-2015 гг., \%

Источник: рассчитано по: Демографический ежегодник Республики Беларусь. Статистический сборник. Минск: 2016; данные Государственной службы статистики Украины. 


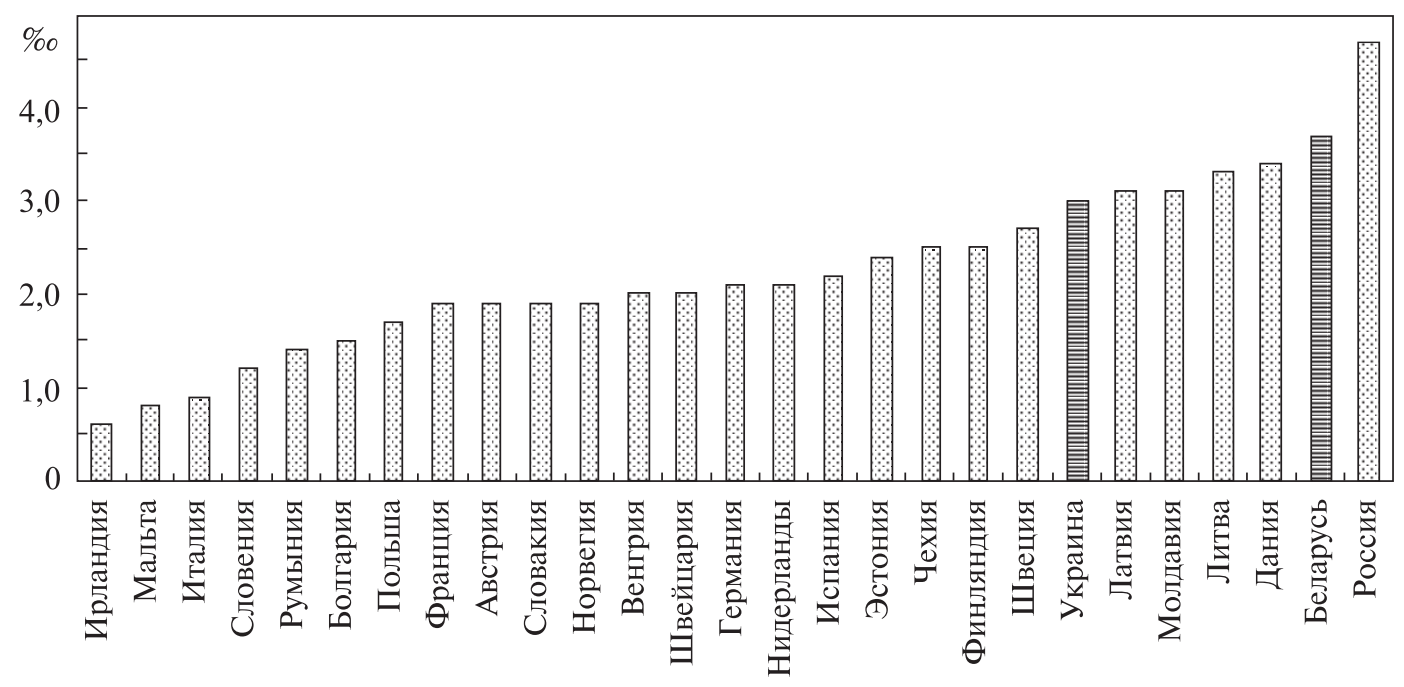

Рис. 6. Общий коэффициент разводимости в Украине, Беларуси и некоторых других странах Европы в 2014 г., \%о

Источник: данные Евростата (http://www.epp.eurostat.ec.europa.eu/tgm/table).

В обеих странах довольно распространена повторная брачность. Повторные браки составляют порядка 1/4 всех регистрируемых браков в Украине, в Беларуси же эта доля на сегодня несколько выше - в среднем почти два из каждых семи зарегистрированных в 2015 г. в республике браков представлены повторными союзами (табл. 1). При этом, если в нашей стране за исследуемый период доля повторных браков изменилась очень незначительно (немного снизилась у мужчин), то в Беларуси прослеживается тенденция к ее увеличению, что может быть связано и с высоким уровнем разводимости, и с довольно распространенной в Украине практикой не регистрации повторных брачных союзов.

Нестабильность брачных отношений, большое количество разводов является острой социально-демографической проблемой как в Украине, так и в Беларуси на протяжении уже нескольких десятилетий. По количеству разводов (в расчете на 1000 населения) обе страны относятся к группе «государств-лидеров» среди европейских стран, в первую очередь это касается Беларуси (рис. 6).

В Украине после 2000 г. общий коэффициент разводимости имеет тенденцию к снижению, хотя и нечетко выраженную, наблюдаются определенные годовые колебания. В Беларуси после довольно значительного снижения уровня разводимости в 2003-2006 гг. прослеживается тенденция к его повышению (рис. 7). Уменьшение количества разводов в Украине обусловлено распространением незарегистрированного брачного сожительства (пара «испытывает» свои отношения еще до официального брака), а также усилением роли фактора «экономической связки» супругов в сложных экономических и военно-политических условиях современной Украины.

Вместе с тем, коэффициент нестабильности брака (соотношение количества зарегистрированных в течение года разводов и браков) в Украине выше, чем в Беларуси. Это дает основания предположить, что более высокие показатели разводимости в Беларуси обусловлены, в первую очередь, ее более высокой зарегистрированной брачностью. 


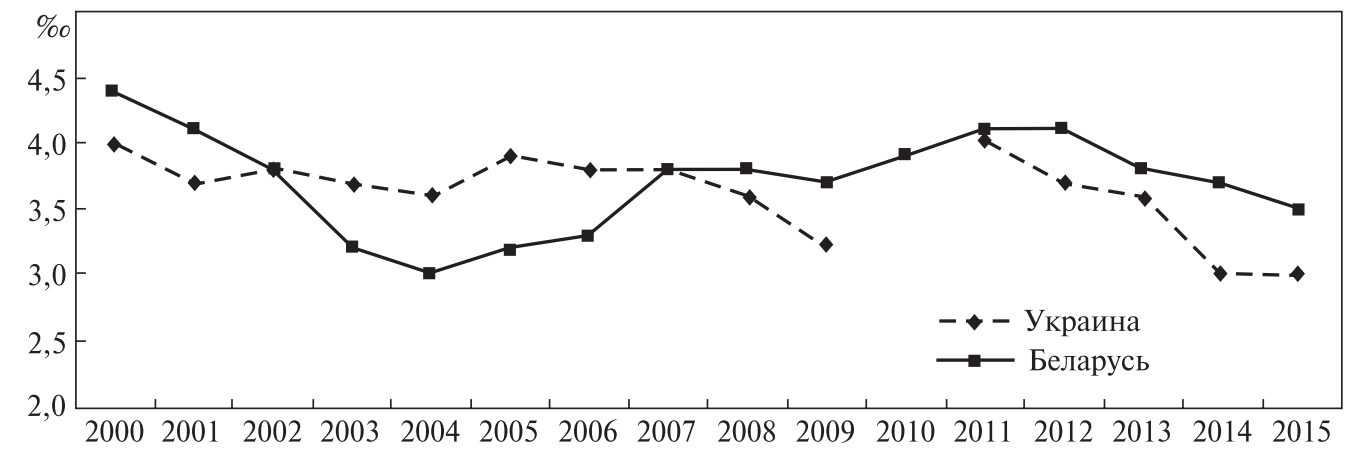

Puc. 7. Общий коэффициент разводимости в Украине и Беларуси в 2000-2015 гг., \%о

Данные по Украине за 2010 год отсутствуют, что обусловлено изменением в июле этого года процедуры регистрации разводов.

Источник: Демографический ежегодник Республики Беларусь. Статистический сборник. - Минск, 2016; данные Государственной службы статистики Украины.

Демографические характеристики распавшихся браков в Украине и Беларуси на протяжении длительного периода весьма схожи: коэффициенты разводимости городского населения значительно выше, чем сельского; наибольший удельный вес разводов фиксируется среди браков небольшой продолжительности - менее 5 лет; более половины брачных пар, которые разводятся, имеют общих детей, но при этом удельный вес таких пар постепенно уменьшается. В большинстве случаев разводящиеся - это однодетные пары. К сожалению, с 2010 г. сравнительный анализ распределения разводов по вышеотмеченным характеристикам стал невозможен из-за отсутствия соответствующих данных в Украине ${ }^{2}$.

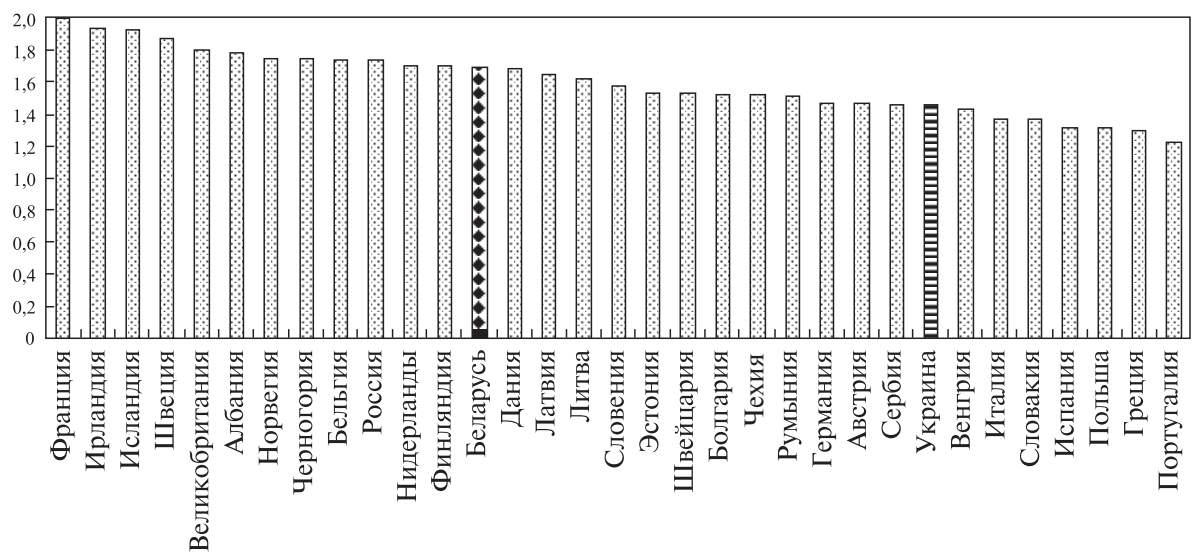

Рис. 8. Суммарный коэффициент рождаемости в Украине, Беларуси и некоторых других странах Европы в 2014 г., детей на одну женщину

Источник: данные Евростата (http://ec.europa.eu/eurostat/data/database).

${ }^{2}$ В июле 2010 г. в Украине был принят закон «О государственной регистрации актов гражданского состояния», который изменил процедуру оформления развода, что негативно повлияло на систему статистического учета. 


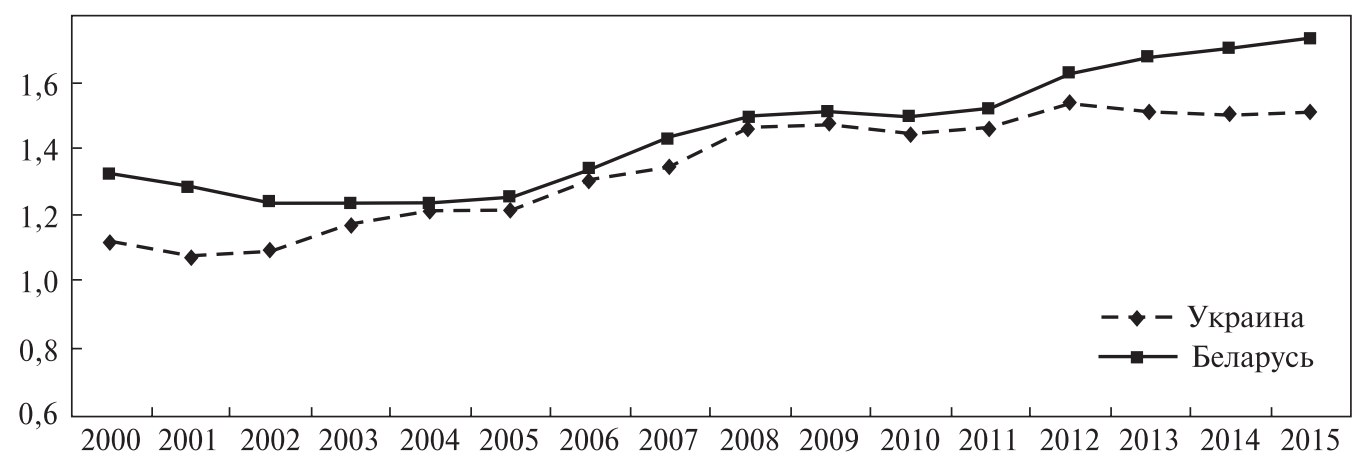

Рис. 9. Суммарный коэффициент рождаемости в Украине и Беларуси в 2000-2015 гг., детей на одну женщину

Источник: Демографический ежегодник Республики Беларусь. Статистический сборник. - Минск, 2016; данные Государственной службы статистики Украины.

Несколько иная ситуация вырисовывается при сравнении рождаемости в двух изучаемых странах. По суммарному показателю рождаемости Беларусь на сегодня находится на одном уровне с Норвегией, Финляндией, Данией, но уступает таким странам как Швеция, Великобритания, Франция, одновременно опережая Швейцарию, Германию, Италию, Испанию и почти все страны, которые были охвачены социалистической системой, в том числе и Украину (рис. 8).

В Украине самый низкий уровень рождаемости был зафиксирован в 2001 г., когда показатель суммарной рождаемости снизился до 1,08 детей на одну женщину. В Беларуси даже в годы самой низкой интенсивности рождаемости (2003-2004 гг.) ее уровень превышал тот, который наблюдался в Украине (рис. 9). Вступление в активный детородный возраст сравнительно многочисленных поколений женщин, родившихся в начале-середине 1980 -х годов, способствовало увеличению численности новорожденных с начала нового тысячелетия. Благоприятными факторами, обусловившими «оживление» собственно детородной активности, стало постепенное улучшение социально-экономической ситуации в комплексе с принимаемыми мерами демографической политики: введением в Украине, начиная с 2005 г., весомой одноразовой денежной помощи при рождении ребенка (с ее постепенным увеличением); принятием в Республике Беларусь «Национальной программы демографической безопасности на 2007-2010 гг.».

Итак, с 2002 г. детородная активность в Украине стала увеличиваться, ее рост наблюдался в течение последующих десяти лет, после чего он приостановился и в последние неблагоприятные в социально-экономическом и военно-политическом плане годы в рождаемости преобладает стагнация. В Украине уровень рождаемости достиг своего наивысшего за исследуемый период значения $(1,53)$ в 2012 г., при этом он оставался заметно ниже, чем в Беларуси.

Суммарный коэффициент рождаемости в Беларуси стал увеличиваться только со второй половины первого десятилетия XXI века, с приостановкой в росте в 2009-2011 гг. В дальнейшем рост рождаемости возобновился с некоторым ускорением темпов, чему могла способствовать активизация пронаталистской политики в этой стране с принятием новой «Национальной программы демографической безопасности Республики Беларусь на 2011-2015 гг.», пересмотром размеров ежемесячных 


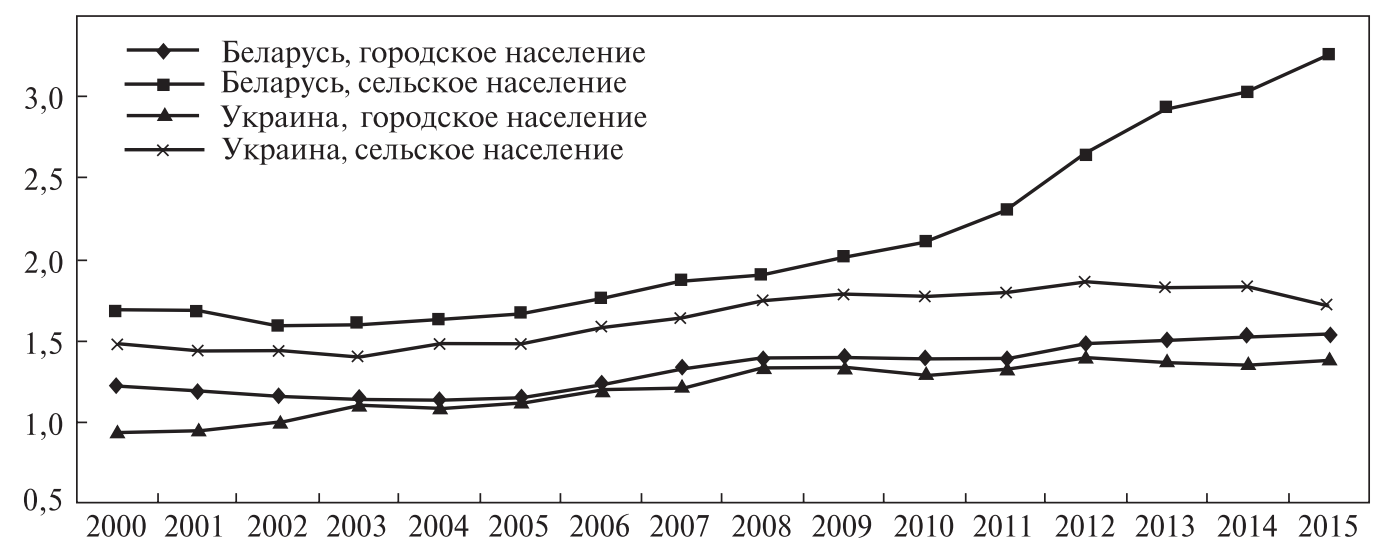

Рис. 10. Суммарный коэффициент рождаемости в городских поселениях и сельской местности Украины и Беларуси в 2000-2015 гг., детей на одну женщину

Источник: Демографический ежегодник Республики Беларусь. Статистический сборник. - Минск, 2016; данные Государственной службы статистики Украины.

пособий по уходу за ребенком в возрасте до 3 лет ${ }^{3}$, увеличением пособия при рождении ребенка и др. В 2015 г. суммарный коэффициент рождаемости в Беларуси составил 1,72 реб. на женщину, что почти на $40 \%$ превышает тот его минимальный уровень, который имел место в 2003-2004 гг. Показательно, что в целом как абсолютные, так относительные различия в уровнях рождаемости между Украиной и Беларусью («в пользу» последней) были максимальными в самом начале и в конце исследуемого периода.

Рассмотрение суммарной рождаемости в межпоселенческом разрезе отчетливо показывает, что тождественность динамики показателя детородной активности характерна для городских поселений рассматриваемых стран, однако в сельской местности, начиная с 2011 г, наблюдается резкая дивергенция значений соответствующего показателя (рис. 10). Вероятно, в немалой степени это объясняется гораздо более выраженным реагированием сельских жителей соседней страны на вводимые в этот период меры пронаталистской политики: интенсивность рождаемости у молодых селянок Беларуси (20-24 лет) за последнее пятилетие увеличилась почти вдвое, в возрасте 25-29 лет - в 1,4 раза, среди 30-34 летних - в 1,6 раза.

Распределение новорожденных по очередности их рождения - важная структурная характеристика, которая «реагирует» на изменения в условиях репродуктивной деятельности населения. Длительный период демографической истории как Украины так и Беларуси характеризовался устойчивым ростом доли первенцев и сокращением доли детей остальных очередностей среди новорожденных. В годы самой низкой рождаемости удельный вес детей, родившихся первыми, достигал 59-60 \%. После 2005 г. наметилась новая тенденция: снижение доли первенцев и увеличения удельного веса рожденных второй и последующих очередностей, причём изменения в Беларуси проходили гораздо стремительнее, чем в Украине, но в обеих странах трансформации в структуре рожденных по очередности рождений были более выраженными в городских поселениях, чем в сельской местности (табл. 2).

3 Периодические пересмотры размеров пособий по уходу за ребенком продолжаются: последнее увеличение было произведено с 1 февраля 2017 г. 
Таблица 2. Структура новорожденных по очерёдности рождения в Украине и Республике Беларусь, \%

\begin{tabular}{|l|c|c|c|c|c|c|c|c|}
\hline \multirow{2}{*}{ Год } & \multicolumn{9}{|c|}{ Украина } & \multicolumn{4}{c|}{ Беларусь } \\
\cline { 2 - 9 } & Первый & Второй & Третий & $\begin{array}{c}\text { Четвер- } \\
\text { тый и } \\
\text { выше }\end{array}$ & Первый & Второй & Третий & $\begin{array}{c}\text { Четвер- } \\
\text { тый и } \\
\text { выше }\end{array}$ \\
\hline 2001 & 66,0 & 27,2 & 4,6 & 2,2 & 62,8 & 31,0 & 4,6 & 1,6 \\
\hline 2003 & 64,9 & 28,6 & 4,5 & 2,0 & 63,2 & 30,7 & 4,5 & 1,6 \\
\hline 2005 & 63,7 & 29,7 & 4,7 & 1,9 & 61,7 & 31,4 & 5,1 & 1,7 \\
\hline 2010 & 54,4 & 35,7 & 7,2 & 2,7 & 53,7 & 37,2 & 7,3 & 1,9 \\
\hline 2015 & 52,0 & 36,2 & 8,5 & 3,3 & 43,5 & 41,9 & 11,6 & 3,1 \\
\hline & & & \multicolumn{7}{|c|}{ Геродские поселения } \\
\hline 2001 & 50,0 & 33,6 & 9,5 & 6,9 & 44,7 & 34,0 & 12,8 & 8,5 \\
\hline 2003 & 50,0 & 33,7 & 9,7 & 6,6 & 47,8 & 32,4 & 12,1 & 7,7 \\
\hline 2005 & 50,3 & 32,8 & 10,1 & 6,8 & 48,7 & 31,3 & 12,5 & 7,4 \\
\hline 2010 & 44,3 & 34,3 & 13,2 & 8,2 & 47,8 & 32,8 & 12,7 & 6,8 \\
\hline 2015 & 45,0 & 32,9 & 12,8 & 9,3 & 40,4 & 35,6 & 16,0 & 8,0 \\
\hline
\end{tabular}

Источник: Демографический ежегодник Республики Беларусь. Статистический сборник. - Минск, 2016; данные Государственной службы статистики Украины.

Нетрудно заметить, что в 2015 г. разница между удельным весом детей, рожденных первыми и вторыми, в Республике Беларусь существенно сократилась (особенно в городских поселениях). Этому предшествовал десятилетний период сближения соответствующих структурных показателей, когда высокий темп снижения удельного веса первенцев сопровождался ростом удельного веса детей, родившихся вторыми.

В Украине сохраняется большой разрыв между удельным весом первенцев и долей детей, рождённых вторыми, что в очерёдной раз подтверждает распространенность однодетности в нашей стране, вопреки тому, что большинство респондентов в ходе выборочных социально-демографических обследований высказало желание иметь двоих детей [13, 14].

В 2015 г. доля детей третьей очередности среди новорожденных в Беларуси также стала выше, чем в Украине. Логично предположить, что такая ситуация была сформирована под влиянием проводимых в Беларуси мер семейной политики, направленных на поддержку семей с несколькими детьми. Среди этих мер - льготное жилищное кредитование многодетных семей, единовременное пособие, дифференцированное по очередности рождений (его размер на второго и последующих новорожденных на 40 \% больше, чем на первого ребенка). Кроме того, с 2015 г. при рождении или усыновлении третьего или последующих детей семья получает право на единовременное предоставление безналичных денежных средств в размере 10000 долл. США. Напомним, что в Украине с июля 2014 г. помощь при рождении ребёнка предоставляется в одинаковом размере на детей разных очерёдностей.

В исследуемый период как Украина, так и Беларусь, вслед за развитыми странами с характерным для них повышением возраста вступления в брак и довольно весомым вкладом в суммарную рождаемость женщин средних и старших репродуктивных групп, были охвачены процессом «постарения материнства». В Беларуси средний 
возраст матери при рождении ребёнка (все очередности рождений) вырос с 25,6 года в 2000 г. до 27,3 года - в 2010 г. и до 28,6 года в 2015 г., тогда как Украина, характеризовавшаяся близкими по значению показателями в 2000 г. $(25,0$ лет) и 2010 г. (27,0 лет), обнаружила значительно меньшую динамичность рассматриваемого процесса в последнее пятилетие, позволив «обогнать себя» многим странам, включая и Беларусь. В Украине средний возраст матери при рождении ребёнка в 2015 г. - 27,2 года.

Средний возраст матери при рождении первого ребёнка в Беларуси также вырос довольно существенно: с 23,3 лет в 2000 г. до 24,9 лет в 2010 г. и до 26,0 лет в 2015 г. В Украине значения показателей составляли 22,9, 24,4 и 24,8 года соответственно. Таким образом, абсолютные и относительные межстрановые различия среднего возраста матери при рождении ребёнка (как по всем очередностям рождения, так и применительно к первенцам) по итогам последнего пятнадцатилетия увеличились.

Как в Украине, так и в Беларуси в разных группах детородного возраста изменения рождаемости в исследуемый период происходили по-разному. В Беларуси в 2005-2008 гг. интенсивность рождений увеличивалась во всех пятилетних группах кроме женщин 15-19 лет. С 2009 г. динамика уровня рождаемости 20-24-летних женщин утратила свою однонаправленность: за небольшим снижением коэффициента рождаемости в этой группе последовало незначительное его повышение, опять сменившееся снижением. В тоже время у женщин среднего и старшего репродуктивного возраста наблюдался относительно устойчивый рост детородной активности. В результате после 2009 г. в Беларуси «лидерство» по интенсивности деторождения перешло к 25-29-летним женщинам: коэффициент рождаемости у них в 2015 г. достиг 115,4 \%о, что на 29,1 \% превышает уровень соседней младшей группы женщин и почти на 40 \% выше, чем у женщин соседней старшей пятилетней репродуктивной группы.

В Украине с 2013 г. хоть и наблюдается тенденция к доминированию в интенсивности деторождения группы 25-29-летних женщин, но превышение весьма незначительно, так что пока ещё рано говорить об устойчивом характере этой тенденции.

Отметим, что уровень рождаемости у женщин 25-29 лет в Беларуси не только ощутимо превышает частоту деторождения в соседних возрастных группах женщин, но и является одним из самых высоких среди европейских стран (уступает только Бельгии, Исландии, Албании и Франции). А вот интенсивность рождаемости и доля рожденных женщинами, старше 30 лет, в Беларуси хотя и существенно увеличилась, но остается ниже, чем в других странах Европы.

Возвращаясь к уровню рождаемости в связи с проблемой воспроизводства населения в целом резюмируем, что значения коэффициента суммарной рождаемости ни в Украине, ни в Беларуси не обеспечивают простое воспроизводство населения. Однако если в Украине этот вывод касается обоих типов поселений (СКР для городского населения составляет 1,39 реб., для сельского - 1,71), то четверть населения Беларуси, проживающая в селах этой страны, благодаря продемонстрированным за последнее пятилетие рекордным темпам роста интенсивности деторождения, достигла в последнее время эксклюзивно высокого (как для европейской страны) значения суммарной рождаемости - 3,26 реб. (против 1,53 - в городском населении в 2015 г.), которое значительно превышает уровень, необходимый для простого воспроизводства.

Наиболее распространенной и точной характеристикой воспроизводства материнского поколения служит нетто-коэффициент воспроизводства, характеризующий степень замещения поколения женщин их дочерьми при длительном сохранении существующих уровней рождаемости и смертности. И ныне, уже после улучшения ситуации по сравнению с той, которая наблюдалась на рубеже веков, режим 


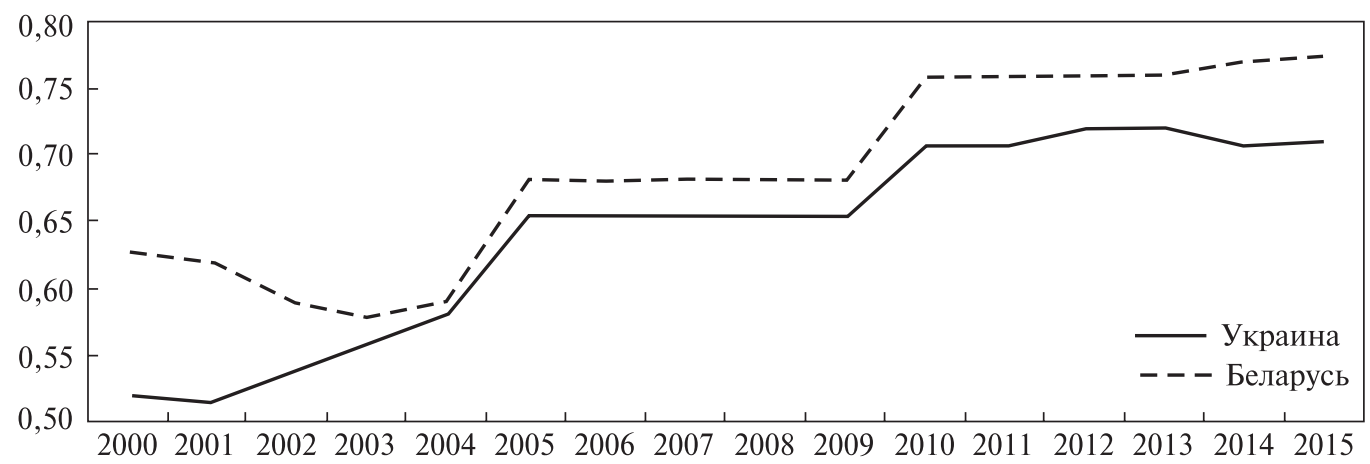

Рис. 11. Нетто-коэффициент воспроизводства населения в Украине и Беларуси в 2000-2015 гг.

Источник: Демографический ежегодник Республики Беларусь. Статистический сборник. - Минск, 2016; данные Государственной службы статистики Украины.

воспроизводства обеспечивает замещение поколений в Украине чуть более чем на 70 \% и в Беларуси - все еще менее чем на 80 \%. Об изменениях показателя за исследуемый период позволяет судить рис. 11.

Проведенный факторный индексный анализ современных различий в уровне нетто-коэффициента воспроизводства в Украине и Беларуси показал, что они в большей мере определяются различиями в уровне рождаемости, нежели межстрановой дифференциацией смертности женщин в репродуктивных возрастах ${ }^{4}$ : согласно значениям рассчитанных субиндексов эти различия ныне почти на 3/4 определяются фактором рождаемости.

Уровни рождаемости изменялись в исследуемый период сильнее, чем женской смертности, соответственно их вклад в динамику нетто-коэффициента воспроизводства (за исследуемый период в целом) также был гораздо более ощутимым.

Выводы и направления развития исследований. Познавательный и объяснительный потенциал сравнительного анализа процессов брачности, рождаемости и воспроизводства населения Беларуси и Украины определяется тем, что данные страны имеют общее политическое, социально-экономическое и демографическое прошлое и связанные с ним схожие социокультурные детерминанты данных процессов.

Отличия в современной модели брачности в Украине и Беларуси минимальны, тем не менее, различия в интенсивности брачности юных женщин (до 20 лет) свидетельствуют об определенной устойчивости национальных брачных традиций, несмотря на меняющуюся социально-экономическую среду. Для обеих стран характерна проблема непрочности брачных отношений, высокий уровень разводимости супружеских пар с детьми, распространение однородительских семей, где детей воспитывает, как правило, только мать.

В отношении рождаемости Украина и Беларусь длительный период имели одинаковые тенденции развития: падение рождаемости сменилось в начале нового тысячелетия её ростом, что сопровождалось снижением удельного веса первенцев и увеличением долей детей второй и последующих очередностей, процессом «постарения материнства». Уровни детородной активности в странах были довольно близки

\footnotetext{
${ }^{4}$ Отметим при этом, что более благоприятная картина дожития женщин в репродуктивном возрасте также наблюдается ныне в Беларуси.
} 
с небольшим преимуществом Беларуси. Однако, начиная с 2012 г., ситуация стала быстро изменятся, что было обусловлено стабилизацией суммарного коэффициента рождаемости в Украине и продолжающимся его ростом в Беларуси. Межпоселенческий анализ показал, что на скорость изменений повлияло главным образом репродуктивное поведение сельских жителей Беларуси, уровень рождаемости у которых менее чем за пять лет вырос в 1,5 раза.

Для исследователей-демографов феномен новейшей динамики рождаемости в Беларуси представляет безусловный интерес: подтвердится ли этой страной правило «доза-эффект», как это было в Украине, когда импульсом для повышения рождаемости являлось очередное увеличение размера денежной помощи при рождении ребенка, или Беларусь станет исключением и рост рождаемости будет наблюдаться даже при отсутствии эскалации пронаталистской политики? Наряду с этим целесообразно детально изучить детородное поведение жителей сельской местности Беларуси и все факторы, повлиявшие на резкое повышение уровня рождаемости.

В целом же результаты проведенного анализа подтверждают перспективность возможных совместных научных разработок в области совершенствования социально-демографической политики, разработки ее мер, направленных на улучшение общей демографической ситуации, в том числе в сфере брачно-семейных отношений и детородной активности населения.

\section{ЛИТЕРАТУРА}

1. Дюркгейм Э.О. разделении общественного труда. Метод социологии / Э. Дюркгейм. - М., 1991. $-576 \mathrm{c}$.

2. Смертність населення України у трудоактивному віці: [монографія] / відп. ред. Е.М. Лібанова; Ін-т демографії та соціальних досліджень НАН України. - К., 2007. - 211 с.

3. Любінець О.В. Особливості та порівняльна характеристика смертності населення від основних причин в Україні та Європі / О.В. Любінець, О.М. Орда // Україна: здоров’я нації. - 2012. № 4 (24). - С. 66-70.

4. Слюсар Л.И. Брачность в Украине и Молдавии в условиях социально-экономической трансформации: общие тенденции и национальные особенности / Л.И. Слюсар, О.Е. Гагауз // Revista de Filozofie, Sociologie şi Ştiințe Politice. - 2011. - № 3. - C. 147-161.

5. Аксенова С. Рождаемость в Украине и Республике Молдова / С. Аксенева, О. Гагауз // Materialele conferinței Evoluția gândirii geografice şi demografice în Republica Moldova. - 2011. - C. 41-49.

6. Пирожков С. Украина и Россия в демографическом измерении / С. Пирожков, Г. Сафарова // Демоскоп Weekly. - 2010. - № 405. - C. 406.

7. Ревун В.И. Демографическое развитие Беларуси, России и Украины в условиях депопуляции : автореф. дисс. ... Д-ра экон. наук / В.И. Ревун. - М. : ИСПИ РАН, 2009.

8. Grigoriev P., Shkolnikov V. M., Andreev, E. M. Jasilionis D., Jdanov D.A, Meslé F., Vallin J. Mortality in Belarus, Lithuania, and Russia: divergence in recent trends and possible explanations // European Journal of Population. - 2010. - № 26: 3. - C. 245-274.

9. Основные вызовы демографической безопасности: сходства и различия в Молдове и Беларуси / Отв. ред. Палади Г.А., Шахотько Л.П., Гагауз О.Е. - Кишинев : Штиинца, 2010. - 296 с.

10. Fertility and Family Policies in Central and Eastern Europe after 1990 // Comparative Population Studies. - 2016. - 41, No. 1. - C. 3-56.

11. Молодежь в Содружестве Независимых Государств: статистический портрет / Статкомитет СНГ. - М. : ЮНФПА, 2014. - 151 с.

12. Щербакова Е. Демографическая ситуация в странах СНГ, 2012 г. / Е. Щербакова // Демоскоп Weekly. - 2013. - № 571-572. [Електронний ресурс]. - Режим доступу: demoscope.ru/weekly/2013/0571/barometer571.pdf 
13. Сім’я та сімейні відносини в Україні: сучасний стан і тенденції розвитку. - К. : Основа-Принт, 2009. $-248 \mathrm{c}$.

14. Цінності української молоді. Соціологічне дослідження становища молоді України. - К., 2016. $-89 \mathrm{c}$.

\section{REFERENCES}

1. Dyurkgeym, E. (1991). O razdelenii obschestvennogo truda. Metod sotsiologii [On the division of social labor. Method of sociology]. Moskow [in Russian].

2. Libanova, E. (Ed.). (2007). Smertnist' naselennya Ukrayiny u trudoaktyvnomu vitsi [The mortality rate of labor force in Ukraine]. K. : In-t demohrafiyi ta sotsial'nykh doslidzhen' im. M.V. Ptukhy NAN Ukrayiny [in Ukrainian].

3. Lyubinets', O.V. (2012). Osoblyvosti ta porivnyal'na kharakterystyka smertnosti naselennya vid osnovnykh prychyn v Ukrayini ta Yevropi [Features and comparative characteristics of mortality from the major causes in Ukraine and Europe]. Ukrayina: zdorov'ya natsiyi - Ukraine: public health, 4(24), 66-70 [in Ukrainian].

4. Slyusar, L.I. \& Gagauz, O.E. (2011). Brachnost v Ukraine i Moldavii v usloviyah sotsialno-ekonomicheskoy transformatsii: obschie tendentsii i natsionalnyie osobennosti [Marriage in Ukraine and Moldova in terms of socio-economic transformation: general trends and national features]. Revista de Filozofie, Sociologie Sociologie şi Ştiințe Politice, 3, 147-161 [in Russian].

5. Aksyonova, S.Y. \& Gagauz, O.E. (2011). Rozhdaemost v Ukraine i Respublike Moldova [The birth rate in Ukraine and the Republic of Moldova]. În: Materialele conferinței Evoluția gândirii geografice şi demografice in Republica Moldova, $41-49$ [in Russian].

6. Pirozhkov, S. \& Safarova, G. (2010). Ukraina i Rossiya v demograficheskom izmerenii [Ukraine and Russia in the demographic dimension]. Demoskop Weekly, 405, 406 [in Russian].

7. Revun, V.I. (2009). Demograficheskoe razvitie Belarusi, Rossii i Ukrainyi v usloviyah depopulyatsii [Demographic development of Belarus, Russia and Ukraine under conditions of depopulation]. Moskow : ISPI RAN [in Russian].

8. Grigoriev, P., Shkolnikov, V.M. \& Andreev, E.M. et al. (2010). Mortality in Belarus, Lithuania, and Russia: divergence in recent trends and possible explanations. European Journal of Population, 26:3, 245-274 [in English].

9. Paladi, G.A., Shahotko, L.P. \& Gagauz, O.E (Ed.). (2010). Osnovnyie vyizovyi demograficheskoy bezopasnosti: shodstva i razlichiya $v$ Moldove i Belarusi [The main challenges of demographic safeness: similarities and differences in Moldova and Belarus]. Kishinev : Shtiintsa [in Russian].

10. Fertility and Family Policies in Central and Eastern Europe after 1990 (2016). Comparative Population Studies, 41, 1, 3-56 [in English].

11. Molodezh v Sodruzhestve Nezavisimyih Gosudarstv: statisticheskiy portret [Youth in the Commonwealth of Independent States: a statistical portrait] (2014). Statkomitet SNG: YuNFPA, 151 [in Russian].

12. Scherbakova, E. (2013). Demograficheskaya situatsiya v stranah SNG, 2012 g. [Demographic situation in the CIS countries, 2012]. Demoskop Weekly, 571-572 Retrieved from http: demoscope.ru/weekly/ 2013/0571/barometer571.pdf [in Russian].

13. Sim'ya ta simeyni vidnosyny v Ukrayini: suchasnyy stan i tendentsiyi rozvytku [Family and family relations in Ukraine: current state and trends] (2009). Kyiv : TOV Osnova-Prynt [in Ukrainian].

14. Tsinnosti ukrayins'koyi molodi. Sotsiolohichne doslidzhennya stanovyshcha molodi Ukrayiny [The values of Ukrainian youth. Sociological study of the situation of youth in Ukraine] (2016). Kyiv [in Ukrainian].

Стаття надійшла до редакції журналу 15.05.2017. 